\title{
Optimization of the fermentation conditions of musts from Pedro Ximénez grapes grown in Southern Spain. Production of higher alcohols and esters
}

\author{
J. Moreno, M. Medina, M.D. Garcia \\ Department of Agricultural Chemistry, Faculty of Sciences, University of Córdoba, Avda. San Alberto Magno s/n, 14071 Córdoba, Spain.
}

Submitted for publication: May 1988

Accepted for publication: August 1988

Keywords: white wine, fermentation, higher alcohols, esters, Pedro Ximénez.

\begin{abstract}
Musts from Vitis vinifera Pedro Ximénez grapes with sugar contents of $191,241,300$ and $342 \mathrm{~g} / \mathrm{l}$ were fermented at controlled temperatures of $15,20,25$ and $30^{\circ} \mathrm{C}$.

The fraction of higher alcohols and esters was determined by GLC in a capillary column. By variance analysis significant differences $(p \leqslant 0,01)$ were obtained in the production of isoamyl alcohols and 2-phenylethanol at the different fermentation temperatures, while the hexanol-1 content was found to depend on the degree of ripeness of the grapes. Only the contents in 2-phenylethyl acetate and ethyl octanoate among the esters assayed were found to depend significantly on the fermentation temperature, and only that of hexyl acetate was found to depend on the degree of ripeness $(\mathbf{p} \leqslant \mathbf{0 , 0 1 )}$.

Taking into account the production of ethanol, higher alcohols and esters, the best results were obtained at fermentation temperatures between $20^{\circ}$ and $25^{\circ} \mathrm{C}$, for both white table wines $(12 \% \mathrm{v} / \mathrm{v}$ ethanol) and sherry type fine wines $(15 \%$ $\mathbf{v} / \mathbf{v}$ ethanol).
\end{abstract}

The major role played by temperature on the fermentation and preservation of wine has long been known for and reviewed by some authors (Dimotaki-Kourakou, 1966; Du Plessis, 1983). However, the literature consulted on the influence of the fermentation temperature on the production of higher alcohols showed somewhat inconsistent results, possibly as a result of disregarding some factors. In this respect, Soufleros and Bertrand (1980) point out that the influence of temperature varies with the yeast used in the fermentation, and Houtman and Du Plessis (1981) remark on the strong influence of must turbidity and fermentation temperature as well as the production of higher alcohols.

The presence of solid suspended matter - whether naturally occurring substances or inert compounds added - favours the formation of higher alcohols (Crowell and Guymon, 1963; Houtman and Du Plessis, 1981). In this respect, Bertrand et al. (1978) found greater production of higher alcohols and ethyl acetate from slurry musts and of higher esters from deslurred musts.

According to Houtman et al. (1980a), the degree of ripeness of the grapes is one of the chief factors affecting the production of volatile acids, alcohols and esters during fermentation. On the other hand, Bertrand (1980) found the maximum contents in higher alcohols and volatile short-chain fatty acids in the fermentation of musts from early grapes.

This work deals with the influence of the fermentation temperature and the degree of ripeness of the grape on the formation of the major fraction of higher alcohols and esters in the alcoholic fermentation of musts from $V$. vinifera Pedro Ximénez grapes, grown in Southern Spain.

\section{MATERIALS AND METHODS}

Grapes of the Vitis vinifera Pedro Ximénez variety were collected at ten-day intervals during the maturation period. The first sampling was carried out on 25 August 1983, while the other three were done on 6, 16 and 27 September of the same year.

Of the approximately $60 \mathrm{~kg}$ of grapes collected on each date, four types of must were obtained by manual pressing. Musts I and II were obtained from unripe grapes, while must III corresponded to the official day of the vintage in the Montilla-Moriles region (Córdoba, Spain) and must IV was pressed out of over-ripe grapes.

The $\mathrm{pH}$ of the musts was adjusted to 3,2 with tartaric acid and enough potassium metabisulphite was added to ensure a total $\mathrm{SO}_{2}$ concentration of $120 \mathrm{mg} / l$. The insoluble solid content was adjusted to $1 \%$ with the decanted and centrifuged slurry, and the contents of an industrial seed tank in tumultuous fermentation was added in a ratio of $10 \%(\mathrm{v} / \mathrm{v})$. The fermentations were conducted on $10 l$ of must at the controlled temperatures of $15,20,25$ and $30^{\circ} \mathrm{C}$.

The inoculum used in all the experiments was obtained from an industrial seed tank and two Saccharomyces cerevisiae races, namely race cerevisiae and race chevalieri, were found to prevail throughout the fermentations carried out at the four temperatures used. Only in the fermentations at $20^{\circ} \mathrm{C}$ was Torulaspora delbrueckii detected more frequently, at the expense of the cerevisiae race. The yeasts were classified according to Kreger Van-Rij (1984). The overall number of yeast cells and of living cells was the subject of a separate study (Moreno et al., 1986).

Samples were analysed at the end of the alcoholic fermentation, when the maximum ethanol content was reached in all the fermentations.

Ethanol was determined according to the method proposed by Crowell and Ough (1979). Higher alcohols and esters were analysed by GLC by means of an SP1000 capillary column $(60 \mathrm{~m}$ in length, $0,32 \mathrm{~mm}$ in dia- 


\begin{tabular}{llrrrr}
\hline COMPOUNDS & MUSTS & \multicolumn{3}{c}{ TEMPERATURES ( $\mathbf{C}$ ) } & $\mathbf{3 0}$ \\
\hline Isobutanol & & $\mathbf{1 5}$ & $\mathbf{2 0}$ & $\mathbf{2 5}$ & $\mathbf{3 0}$ \\
& I & 131,0 & 115,0 & 115,6 & 198,7 \\
& II & 90,3 & 96,7 & 144,1 & 147,7 \\
& III & 104,2 & 109,7 & 92,0 & 188,8 \\
& IV & 129,2 & 85,3 & 179,0 & 122,0 \\
\hline 1-butanol & I & 0,46 & 1,13 & 0,60 & 0,49 \\
& II & 2,77 & 0,38 & 0,33 & 1,92 \\
& III & 1,56 & 2,92 & 1,52 & 1,04 \\
& IV & 2,33 & 0,73 & 1,04 & 2,04 \\
\hline Isoamylics & I & 111,0 & 162,7 & 336,2 & 350,5 \\
& II & 97,6 & 192,1 & 228,7 & 326,9 \\
& III & 69,6 & 193,5 & 217,0 & 178,4 \\
& IV & 106,4 & 125,7 & 211,8 & 191,3 \\
\hline 1-hexanol & I & 0,82 & 0,78 & 0,91 & 1,05 \\
& II & 0,58 & 0,57 & 0,57 & 0,62 \\
& III & 0,44 & 0,53 & 0,46 & 0,53 \\
& IV & 0,47 & 0,40 & 0,41 & 0,41 \\
\hline 2-phenyl & I & 22,3 & 34,0 & 76,4 & 60,6 \\
ethanol & II & 24,3 & 41,7 & 92,2 & 59,1 \\
& III & 31,7 & 31,2 & 43,8 & 37,1 \\
& IV & 32,0 & 31,2 & 58,1 & 39,9 \\
\hline Ethanol & I & 12,5 & 12,5 & 12,5 & 11,8 \\
& II & 13,8 & 14,5 & 14,6 & 13,5 \\
& III & 14,7 & 15,9 & 15,1 & 14,2 \\
& IV & 14,4 & 15,1 & 15,6 & 13,7 \\
\hline
\end{tabular}

TABLE 1

Production of higher alcohols (mg/l) and ethanol (\% v/v).

\begin{tabular}{llrrrr}
\hline COMPOUNDS & MUSTS & \multicolumn{3}{c}{ TEMPERATURES $\left({ }^{\circ} \mathbf{C}\right)$} & $\mathbf{3 0}$ \\
\hline Ethyl & & $\mathbf{1 5}$ & $\mathbf{2 0}$ & $\mathbf{2 5}$ & $\mathbf{3 0}$ \\
acetate & I & 112,7 & 210,1 & 93,8 & 202,5 \\
& II & 91,4 & 127,0 & 98,3 & 119,3 \\
& III & 110,1 & 219,8 & 152,8 & 92,0 \\
\hline Propyl & IV & 111,6 & 89,6 & 104,6 & 89,0 \\
acetate & I & 1,04 & 0,92 & 0,40 & 0,61 \\
& II & 0,58 & tr, & 1,07 & 0,67 \\
& III & 0,55 & 0,76 & 1,07 & 1,01 \\
\hline Isobutyl & IV & 0,92 & 0,76 & 0,82 & 0,73 \\
acetate & I & 0,46 & 0,33 & 0,43 & 0,79 \\
& II & 0,49 & 0,36 & tr, & 0,27 \\
& III & 0,49 & 0,73 & 0,52 & 0,18 \\
Isoamyl & IV & 0,40 & 0,24 & 0,30 & tr, \\
acetate & I & 1,85 & 1,82 & 5,08 & 5,12 \\
& II & 1,95 & 2,14 & 2,92 & 2,89 \\
& III & 1,49 & 3,76 & 4,62 & 2,32 \\
\hline Hexyl & IV & 1,00 & 0,79 & 2,43 & 0,41 \\
acetate & I & 0,36 & 0,63 & 0,56 & 0,62 \\
& II & 0,19 & 0,24 & 0,25 & 0,33 \\
& III & 0,45 & 0,25 & 0,29 & 0,27 \\
\hline 2-phenyl & IV & tr, & 0,22 & 0,20 & 0,31 \\
ethyl & I & 0,14 & 0,22 & 0,89 & 0,52 \\
acetate & II & 0,19 & 0,30 & 1,35 & 0,76 \\
& III & 0,23 & 0,31 & 0,91 & 0,56 \\
& IV & 0,11 & 0,12 & 0,75 & 0,26 \\
\hline
\end{tabular}

TABLE 2

Production of esters of acetic acid $(\mathrm{mg} / l)$. 


\begin{tabular}{llllll}
\hline COMPOUNDS & MUSTS & \multicolumn{3}{c}{ TEMPERATURES $\left({ }^{\circ} \mathbf{C}\right)$} & $\mathbf{3 0}$ \\
\hline Ethyl & & $\mathbf{1 5}$ & $\mathbf{2 0}$ & $\mathbf{2 5}$ & $\mathbf{3 0}$ \\
hexanoate & I & 0,63 & 0,56 & 1,10 & 1,59 \\
& II & 0,69 & 0,73 & 1,17 & 0,48 \\
& III & 0,83 & 1,16 & 1,31 & 0,55 \\
\hline Ethyl & IV & 0,46 & 0,38 & 0,80 & 0,07 \\
octanoate & I & 0,47 & 0,36 & 1,18 & 0,16 \\
& II & 0,63 & 0,83 & 1,48 & 0,57 \\
& III & 0,92 & 1,28 & 1,25 & 0,59 \\
\hline Ethyl & IV & 0,69 & 0,60 & 0,79 & 0,24 \\
decanoate & I & 0,06 & tr, & 0,09 & 0,40 \\
& II & 0,07 & 0,09 & 0,16 & 0,15 \\
& III & 0,22 & 0,25 & 0,35 & 0,09 \\
\hline Ethyl & IV & 0,25 & 0,14 & 0,25 & 0,25 \\
lactate & I & 0,46 & 1,56 & 1,25 & 0,94 \\
& II & 0,43 & 0,58 & 0,70 & 1,07 \\
& III & 1,93 & 0,49 & 0,40 & 0,82 \\
\hline Hexyl & IV & 1,65 & 0,18 & 0,73 & 1,16 \\
lactate & I & 0,75 & 1,03 & 1,57 & 1,57 \\
& II & 0,55 & 1,26 & 1,11 & 1,48 \\
& III & 0,83 & 0,83 & 0,89 & 1,08 \\
\hline Diethyl & IV & 0,75 & 0,43 & 1,44 & 1,51 \\
succinate & I & 0,15 & 0,16 & 0,30 & 1,25 \\
& II & 0,13 & 0,24 & 1,11 & 0,59 \\
& III & 0,21 & 0,41 & 1,07 & 0,55 \\
& IV & 0,14 & 0,12 & 0,90 & 0,24 \\
\hline
\end{tabular}

TABLE 3

Production of hexyl lactate, ethyl esters of C-6, C-8, C-10, lactic and succinic acids (mg/l).

meter) after separation of the compounds of interest with the aid of Chromosorb 101 and the technique developed by Diaz (1979).

The higher alcohols and esters quantified were those occurring in greater concentrations: isobutanol, isoamyl alcohols, butanol-1, hexanol-1, 2-phenylethyl alcohol; ethyl, propyl, isobutyl, isoamyl and 2-phenylethyl acetates, the ethyl esters of the acids of 6,8 and 10 carbon atoms, ethyl and hexyl lactate and diethyl succinate. All these were quantified from the calibration curves obtained for solutions of known concentrations subjected to the same treatment as the samples. All correlation coefficients were greater than 0,99 . The internal standard used was octanol-2.

\section{RESULTS AND DISCUSSION}

The experimental musts were characterized by reducing sugar contents of $191 \mathrm{~g} / \mathrm{l}$ (must I), $241 \mathrm{~g} / \mathrm{l}$ (must II), $300 \mathrm{~g} / l$ (must III) and $342 \mathrm{~g} / l$ (must IV). The high sugar concentration of musts III van IV, not consumed by the yeasts during the alcoholic fermentation, facilitated the study of the fermentations carried out under extreme conditions.

Although the inoculum used in all the experiments was the same, the yeast populations were found to fluctuate in the course of the fermentations, in all of which $S$. cerevisiae race cerevisiae and race chevalieri were isolated as prevalent. These yeasts were also detected in the fermentations carried out at $20^{\circ} \mathrm{C}$, where $T$. delbrueckii was found to occur with greater frequencies (Mauricio et al., 1986).

The ethanol contents found in the 16 fermentations are listed in table 1. For all the degrees of ripeness considered, the greatest production of ethanol corresponded to the temperatures of 20 and $25^{\circ} \mathrm{C}$. The lowest contents observed at $30^{\circ} \mathrm{C}$ reflect the negative influence of high fermentation temperatures on the

\begin{tabular}{lcc}
\hline \multicolumn{1}{c}{ COMPOUNDS } & \multicolumn{2}{c}{ F ratio } \\
& Temperatures & Maturity \\
\hline Ethanol & $10,64^{* *}$ & $47,87^{* *}$ \\
Isobutanol & 13,03 & 0,32 \\
1-butanol & 0,74 & 1,19 \\
Isoamylics & $10,45^{* *}$ & 2,66 \\
1-pentanol & 3,53 & 1,06 \\
1-hexanol & 1,40 & $41,41^{* *}$ \\
1-octanol & 1,94 & 1,14 \\
2-phenyl etanol & $9,88^{* *}$ & 2,12 \\
Total higher alcohols & $12,85^{* *}$ & 2,44 \\
Propyl acetate & 0,37 & 0,54 \\
Isobutyl acetate & 0,59 & 1,34 \\
Isoamyl acetate & 3,42 & $3,95^{*}$ \\
Hexyl acetate & 1,11 & $8,96^{* *}$ \\
2-phenyl ethyl acetate & $39,54^{* *}$ & $5,85^{*}$ \\
Total acetates of higher alc. & $5,45^{*}$ & $5,50^{*}$ \\
Ethyl acetate & 1,53 & 1,81 \\
Ethyl hexanoate & 1,54 & 2,26 \\
Ethyl octanoate & $11,26^{* *}$ & $5,56^{*}$ \\
Ethyl decanoate & 0,75 & 1,00 \\
Total esters of C6, C8, C10 & $4,34^{*}$ & 2,45 \\
Ethyl lactate & 0,44 & 0,26 \\
Hexyl lactate & $5,76^{*}$ & 1,03 \\
Total lactates & 0,79 & 0,34 \\
Diethyl succinate & $4,32^{*}$ & 0,32 \\
Total esters (- Ethyl acetate) & $5,92^{*}$ & 3,73 \\
\hline
\end{tabular}

TABLE 4

Analysis of variance. Degrees of freedom: $3 / 9 .\left({ }^{* *}, \mathrm{p} \leqslant 0.01, \mathrm{~F}=6.99\right)$; $(*, p \leqslant 0.05, F=3.86)$. 
production of ethanol, especially in musts with high sugar contents.

The fermentation rate was especially affected by the temperature. Thus, the maximum ethanol content was obtained after 15 days in the fermentations carried out at $15^{\circ} \mathrm{C}$. Musts II, III and IV yielded their highest ethanol content after 13 days in the fermentations conducted at $20^{\circ} \mathrm{C}$, while must I did so after 10 days. The fermentations carried out at $25^{\circ} \mathrm{C}$ and $30^{\circ} \mathrm{C}$ yielded the highest ethanol contents after 8 and 7 days, respectively, for all musts.

The higher alcohol concentrations corresponding to the maximum alcoholic degree are given in Table 1.

The variance analysis (Table 4) of the higher alcohol contents reflects that only isoamyl alcohols and 2-phenylethanol vary significantly (level above $99 \%$ ) with the fermentation temperature, while hexanol-1 shows significant differences with the degree of ripeness, its highest contents corresponding to the must from unripe grapes.

The sum of the final contents in higher alcohols depends significantly (99\%) on the fermentation temperature, which is consistent with the findings of other authors (Houtman and Du Plessis, 1981; Poulard et al., 1983; Ciolfi et al., 1985). On the other hand, no significant differences were found in this work between the degrees of ripeness. However, Bertrand (1980) found an inverse relationship, though only significant at the $95 \%$ level. One should probably consider the distortion due to the high sugar content in must IV in this respect.

In Table 2 are listed the contents in the acetic esters assayed, the most highly concentrated of which was ethyl acetate. The production of this compound was found not to depend significantly on the fermentation temperature or the degree of ripeness (Table 4).

The esters from acetic acid and higher alcohols were found in the following decreasing order of concentration at the end of the alcoholic fermentation: Isoamyl acetate $>$ propyl acetate $>$ isobutyl acetate $>$ hexyl acetate $>2$-phenylethyl acetate. The variance analysis of the results obtained showed significant differences with the degree of ripeness in the contents in isoamyl and 2-phenylethyl acetate at the $95 \%$ level and in that of hexyl acetate at the $99 \%$ level. Likewise, 2-phenylethyl acetate showed significant differences with the temperature at the $99 \%$ level (Table 4). However, the sum of the contents in the acetates of higher alcohols showed significant differences with the two above-mentioned variables at the $95 \%$ level.

The contents in the ethyl esters of the acids of 6,8 and 10 carbon atoms (Table 3) decreased with the length of the carbon chain. This has also been observed and accounted for on the basis of the greater solubility of long-chain esters in lipids (Nykanen, 1986).

With the exception of the results obtained at $30^{\circ} \mathrm{C}$, the production of the different ethyl esters of the acids of $\mathrm{C}_{6}, \mathrm{C}_{8}$ and $\mathrm{C}_{10}$ increased with higher fermentation temperature. However, Houtman and $\mathrm{Du}$ Plessis (1981) found the production of ethyl esters of fatty acids to be relatively independent of the fermentation conditions, while Soufleros and Bertrand (1980) found low temperatures to favour the synthesis of these compounds by $S$. cerevisiae. Ough (1982) obtained the highest contents in ethyl hexanoate at $20^{\circ} \mathrm{C}$ and those of ethyl octanoate and decanoate at $15^{\circ} \mathrm{C}$. The highest contents in these esters were generally obtained at $25^{\circ} \mathrm{C}$ in the present study.

From the results in Table 3 follows that the production of these esters increased with increasing degree of ripeness, except for must IV, which is in agreement with the results found by Houtman et al. $(1980 \mathrm{a}, \mathrm{b})$ and Bertrand (1980). However, the variance analysis (Table 4) applied to the final content in each ester at the end of the fermentations carried out at all four temperatures for the four degrees of ripeness considered only shows significant differences in the production of ethyl octanoate with the temperature $(99 \%)$ and the degree of ripeness $(95 \%)$. The sum of the contents in the ethyl esters of the acids of $\mathrm{C}_{6}, \mathrm{C}_{8}$ and $\mathrm{C}_{10}$ only shows significant differences $(95 \%)$ with the fermentation temperature.

The last group of esters was formed by ethyl and hexyl lactate and by diethyl succinate. Their contents are given in Table 3 .

The concentrations of hexyl lactate and diethyl succinate are related at the $95 \%$ level with the fermentation temperature (Table 4). Both esters were produced in greater concentrations in the musts fermented at the higher temperatures. Poulard et al. (1983) also found higher contents in diethyl succinate at fermentation temperatures between $26^{\circ}$ and $28^{\circ} \mathrm{C}$.

Finally, the sum of the contents in all the esters assayed except ethyl acetate shows significant differences $(95 \%)$ with the fermentation temperature (Table 4$)$.

\section{CONCLUSIONS}

The sum of the final contents in the higher alcohols assayed shows significant differences $(p \leqslant 0,01)$ with the fermentation temperatures because of the dependence of the concentrations of isoamyl alcohols and 2-phenylethanol on this factor.

Ethyl acetate shows no significant differences with the temperature or the degree of ripeness of the grapes. Conversely, the sum of the contents in the remainder of esters assayed does differ significantly $(p \leqslant 0,05)$ with the fermentation temperature, on which the concentrations of 2-phenylethyl acetate, ethyl octanoate, hexyl lactate and diethyl succinate depend.

Taking into account the higher fermentation rate, greater ethanol production and average contents in higher alcohols and ethyl acetate, as well as the greater production of other esters, the best results are obtained at temperatures between $20^{\circ}$ and $25^{\circ} \mathrm{C}$, both in the production of white table wines with ethanol contents close to $12 \%(\mathrm{v} / \mathrm{v})$ and in the natural obtainment of fine white, sherry-type wines with ethanol contents of about $15 \%(\mathrm{v} / \mathrm{v})$.

\section{LITERATURE CITED}

BERTRAND, A., 1980. Influence de la maturation de la vendage sur la teneur en substances volatiles des vin. Connais. Vigne Vin. 14, 203-205.

BERTRAND, A., MARLY-BRUGEROLLE, C. \& SARRE, C., 1978. Influence du debourbage des mouts et du sulfitage sur la teneur en substances volatiles des vins et des eaux de vie. I. Etude des vins. Connais. Vigne Vin. 12, 35-48.

CIOLFI, C., CASTINO, M. \& DI STEFANO, R., 1985. Studio sulla risposta metabolica di lieviti di specie diverse fermentanti un unico mosto a temperature comprese fra 10 e $40^{\circ} \mathrm{C}$. Nota I. Riv. Vitic. Enol. Conegliano 9, 447-470. 
CIOLFI, C., CASTINO, M. \& DI STEFANO, R., 1985. Studi sulla risposta metabolica di lieviti di specie diverse fermentanti un unico mosto a temperature comprese fra 10 e $40^{\circ} \mathrm{C}$. Nota II. Riv. Vitic. Enol. Conegliano 10, 489-507.

CROWELL, E.A. \& GUYMON, J.F., 1963. Influence of aeration and suspended material on higher alcohols, acetoin and diacetyl during fermentation. Am. J. Enol. Vitic. 14, 214-222.

CROWELL, E.A. \& OUGH, C.S., 1979. A modified procedure for alcohol determination by dichromate oxidation. Am. J. Enol. Vitic. 30, 61-63.

DIAZ, M.I., 1979. Contribution a l'etude des substances volatiles des raisins et des vins de Muscat. Thèse $3^{\text {eme }}$ Cycle. Univ. Bordeaux II.

DIMOTAKI-KOURAKOU, V., 1966. Influence des températures de fermentation et de conservation du vin et des vins spéciaux sur leurs caractères organoleptiques. Bull OIV. 419, 73-102, 191-222, 327-355, 487-497.

DU PLESSIS, C. S., 1983. Influence de la température d'elaboration et de conservation sur les charactéristiques physico-chimiques et organoleptiques des vins. Bull OIV. 624, 104-115.

HOUTMAN, A.C. \& DU PLESSIS, C.S., 1981. The effect of juice clarity and several conditions promoting yeast growth on fermentation rate, the production of aroma components and wine quality. S. Afric. J. Enol. Vitic. 2, 71-81.

HOUTMAN, A.C., MARAIS, J. \& DU PLESSIS, C.S., 1980a. Factors affecting the reproducibility of fermentation of grape juice and of the aroma composition of wines. I. Grape maturity, sugar, inoculum concentration, aeration, juice turbidity and ergosterol. Vitis 19, 37-54.
HOUTMAN, A.C., MARAIS, J. \& DU PLESSIS, C.S., 1980b. The possibilities of applying present-day knowledge of wine aroma components. Influence of several juice factors on fermentation rate and ester production during fermentation. S. Afric. J. Enol. Vitic. 1, 27-34.

KREGER VAN-RIJ, N.J.W., 1984. The yeasts. A taxonomic study. 3rd ed. Elsevier Sci. Pub. B. V. Amsterdam.

MAURICIO, J.C., MORENO, J., MEDINA, M. \& ORTEGA, J.M., 1986. Fermentation of "Pedro Ximénez" musts at various temperatures and different degrees of ripeness. Belg. J. Food. Chem. Biotechnol. 41 (3), 71-76.

MORENO, J., MAURICIO, J.C., ORTEGA, J.M. \& MEDINA, M., 1986. Choix de la température de fermentation la mieux adaptée pour l'élaboration des vins blancs à partir du cépage "Pedro Ximénez" dans le sud de l'Espagne. Connais. Vigne Vin. 20 (2), 97-106.

NYKANEN, L., 1986. Formation and occurrence of flavor compounds in wine and distilled alcoholic beverages. Am. J. Enol. Vitic. 37, 84-96.

OUGH, C.S., 1982. Volatile esters in wines. Source and fate. Symp. Proc. "Grape and wine centennial". Univ. California. Davis 336-341.

POULARD, A., BRELET, M. \& ROUSSET, Y., 1983. Choix d'une température dans les vinifications en blanc sec. Incidence sur la composition et la qualité des vins. Vignes et vins 326, 31-37.

SOUFLEROS, E. \& BERTRAND, A., 1980. Incidence de l'action conjuguée de la température de fermentation et l'acidité du milieu sur les teneurs en substances volatiles formées par les levures. Connais. Vigne Vin. 14, 97-109. 